University of Nebraska - Lincoln

DigitalCommons@University of Nebraska - Lincoln

USDA National Wildlife Research Center - Staff Publications
U.S. Department of Agriculture: Animal and Plant Health Inspection Service

2011

\title{
Comparing a Bioenergetics Model With Feeding Rates of Caged European Starlings
}

H. Jeffrey Homan

USDA/APHIS/Wildlife Services' National Wildlife Research Center, jeffrey.h.homan@aphis.usda.gov

Randal S. Stahl

USDA-APHIS-Wildlife Services, randal.s.stahl@aphis.usda.gov

George M. Linz

USDA/APHIS/WS National Wildlife Research Center, george.m.linz@aphis.usda.gov

Follow this and additional works at: https://digitalcommons.unl.edu/icwdm_usdanwrc

Homan, H. Jeffrey; Stahl, Randal S.; and Linz, George M., "Comparing a Bioenergetics Model With Feeding Rates of Caged European Starlings" (2011). USDA National Wildlife Research Center - Staff Publications. 1322.

https://digitalcommons.unl.edu/icwdm_usdanwrc/1322

This Article is brought to you for free and open access by the U.S. Department of Agriculture: Animal and Plant Health Inspection Service at DigitalCommons@University of Nebraska - Lincoln. It has been accepted for inclusion in USDA National Wildlife Research Center - Staff Publications by an authorized administrator of DigitalCommons@University of Nebraska - Lincoln. 


\title{
Comparing a Bioenergetics Model With Feeding Rates of Caged European Starlings
}

\author{
H. JEFFREY HOMAN, ${ }^{\mathbf{1}}$ U.S. Department of Agriculture, Animal Plant Health Inspection Service, Wildlife Services, National Wildlife Research \\ Center, 2110 Miriam Circle, Suite B, Bismarck, ND 58501, USA \\ RANDAL S. STAHL, U.S. Department of Agriculture, Animal Plant Health Inspection Service, Wildlife Services, National Wildlife Research Center, \\ 4101 LaPorte Avenue, Fort Collins, CO 80521, USA \\ GEORGE M. LINZ, U.S. Department of Agriculture, Animal Plant Health Inspection Service, Wildlife Services, National Wildlife Research Center, \\ 2110 Miriam Circle, Suite B, Bismarck, ND 58501, USA
}

\begin{abstract}
We tested a bioenergetics model integrated within a mortality model that estimates numbers of European starlings (Sturnus vulgaris) poisoned with the avicide, Compound DRC-1339 Concentrate. The bioenergetics model predicted daily metabolic rate. Accuracy and reliability of this variable is critical because other algorithms (e.g., toxicity regressions, feeding behavior) in the mortality model depend on metabolic rate to calculate the amount of DRC-1339 ingested per bird. We tested the bioenergetics model by comparing its estimates of metabolic rate with those generated from measuring feeding rates of caged starlings during a feeding trial conducted outdoors during January 2008. Over the 12-day feeding trial, daily feeding rates of caged starlings indicated that metabolic rates ranged from $157 \mathrm{~kJ} / \mathrm{bird}$ per day to $305 \mathrm{~kJ} / \mathrm{bird}$ per day. The bioenergetics model predicted metabolic rates ranging from $208 \mathrm{~kJ} / \mathrm{bird}$ per day to $274 \mathrm{~kJ} / \mathrm{bird}$ per day. There was no difference between these 2 independently derived estimates of daily metabolic rate (paired $t$-test: $t_{(11)}=1.4, P=0.18$ ). Using $95 \%$ confidence intervals calculated from variation of feeding rates among cages ( $n=4,6$ birds/cage), the bioenergetics model's estimates were within $95 \%$ confidence intervals on 9 of 12 days and greater than the upper $95 \%$ confidence interval on 3 days. Daily estimates of metabolic rate were directly correlated between the bioenergetics model and the feeding-rate model $\left(r_{12}=0.57, P=0.05\right)$. A broad range of temperatures $\left(-17^{\circ} \mathrm{C}\right.$ to $\left.14^{\circ} \mathrm{C}\right)$, wind speeds $(0-40 \mathrm{~km} /$ $\mathrm{hr}$ ), and percent cloud cover (0-100\%) were encountered during the feeding trial. The bioenergetics model's predictions appeared robust to varying meteorological conditions typical of winters in middle latitudes of the interior United States. Compound DRC-1339 Concentrate is used by USDA Wildlife Services to manage chronic infestations of starlings at livestock facilities, which occur mainly during fall and winter. Compared to other methods used for estimating DRC-1339 mortality (e.g., counting birds pre- and posttreatment), bioenergetics modeling should improve the mortality model's overall accuracy and precision. (c) 2011 The Wildlife Society. ${ }^{\dagger}$
\end{abstract}

KEY WORDS bioenergetics, DRC-1339, European starlings, feeding trial, metabolic rate, Sturnus vulgaris, winter.

Seminal research in the field of environmental biophysics has allowed quantitative modeling of avian metabolism to become an accurate technique for estimating daily energy requirements (Calder and King 1974, Bakken and Gates 1975, Robinson et al. 1976, Campbell 1977, Kendeigh et al. 1977). Several avian bioenergetics models have been developed and applied under field conditions, and modeled metabolic rates have been comparable to estimates from heated taxidermic mounts and other types of energetic models, such as those using doubly labeled water (DLW) with allometric scaling (Kelty and Lustick 1977, Mahoney and King 1977, Walsberg and King 1980, Wiersma and Piersma 1994, Nagy et al. 1999). Rarely, however, have comparisons been made between modeled estimates and estimates made through observations of feeding behavior (Pitt et al. 1998).

Empirical knowledge on reliability and accuracy of modeled metabolic rates of European starlings (hereafter starlings) is important, because we developed a quantitative model that uses environmental biophysics and avian energetics (i.e., bioenergetics) to help estimate starling mortality following applications of DRC-1339 Concentrate at livestock facilities (Compound DRC-1339 Concentrate-

Received: 4 December 2009; Accepted: 4 May 2010

${ }^{\dagger}$ This article is a U.S. Government work, and as such, is in the public domain in the United States of America.

${ }^{1}$ E-mail: jeffrey.h.homan@aphis.usda.gov
Feedlots, U.S. Environmental Protection Agency Reg. No. 56228-10; U.S. Department of Agriculture Animal and Plant Health Inspection Service, Riverdale, MD). In addition to using bioenergetics, the mortality model incorporates algorithms based on DRC-1339 toxicological data and feeding behavior simulations (and their related distributions of probability) that convert the bioenergetics analysis into a quantifiable estimate of mortality (DeCino et al. 1966, Glahn et al. 1983, Johnston et al. 2007). Thus, accuracy of the mortality model's estimate is dependent on accuracy of the integrated bioenergetics model. To help assess accuracy of the bioenergetics model, we compared its prediction with the energy requirements of maintenance metabolism for caged starlings held outdoors during a feeding trial conducted in central Kansas during January 2008. Our objective was to ensure that avian bioenergetics simulation models were capable of making realistic estimates of daily metabolic rates during differing environmental conditions encountered in winter.

\section{MODEL THEORY}

The following is a cursory explanation of the theory and principles of biophysics and bioenergetics. Brief summations of the formulae and theoretical foundation used for development of avian bioenergetics models can be referenced in Mahoney and King (1977) and Cartar and Guy Morrison (1997); more thorough treatments can be found in Calder and King (1974), Bakken (1976), Robinson et al. (1976), 
Campbell (1977), and Campbell and Norman (1998). Maintenance metabolism accounts for energetic costs incurred by a resting homeotherm and does not include energetic costs of major physical activities (e.g., flying). Maintenance metabolism can be divided into basal and thermoregulatory processes. Basal metabolism $\left(B_{\mathrm{M}}\right)$ supports the fundamental physiological mechanisms of life (e.g., breathing, blood circulation, smooth muscle contractions, and ion gradient differentials) and maintains cells and organs at resting physiological states. Basal metabolism has a fixed energetic cost that is mass dependent and can be expressed by the following function:

$B_{\mathrm{M}}=C m^{\mathrm{e}}$

where $C$ is a constant, $m$ is the organism's mass ( $\mathrm{kg})$, and e is an exponent of mass, which for passerines ranges between 0.6 and 0.7 (Aschoff and Pohl 1970, Kendeigh 1970, Nagy et al. 1999). Thermoregulatory metabolism in homeotherms is required when environmental conditions are such that a stable core body temperature can no longer be maintained. The metabolic cost of thermoregulation is an inverse linear function with environmental temperature (Kendeigh 1969).

The relationship of metabolic rate $(M)$ to environmental energy flux can be described as:

$M-\lambda E=\rho c_{\mathrm{p}} \frac{T_{\mathrm{b}}-T_{\mathrm{e}}}{r_{\mathrm{b}}+r_{\mathrm{e}}}$

where $\lambda E$ is evaporative heat loss, $\rho c_{\mathrm{p}}$ is the product of air density $\times$ specific heat capacity of air, $T_{\mathrm{b}}$ is core body temperature, $T_{\mathrm{e}}$ is environmental temperature, $r_{\mathrm{b}}$ is wholebody thermal resistance, and $r_{\mathrm{e}}$ is the sum of parallel resistances at the body-surface to radiative heat loss $\left(r_{\mathrm{r}}\right)$ and convective heat loss $\left(r_{\mathrm{a}}\right)$. The $r_{\mathrm{a}}$ term consists of resistances to free convection $\left(r_{\mathrm{fr}}\right)$ and forced convection $\left(r_{\mathrm{fo}}\right)$. The right side of equation 2 describes the thermal gradient that exists at the interface between body surface and environment. The $\rho c_{\mathrm{p}}$ term is the capacity of air to absorb heat at the boundary layer that surrounds the body surface. The terms $\left(T_{\mathrm{b}}-T_{\mathrm{e}}\right) /\left(r_{\mathrm{b}}+r_{\mathrm{e}}\right)$ combine the strength of the heat energy gradient (numerator) and the ability to mitigate the gradient's strength through resistances to heat energy transfer (denominator). Resistance factors, $r_{\mathrm{b}}$ and $r_{\mathrm{e}}$, incorporate morphological, physical, and physiological attributes of the organism. In avian bioenergetics these can include feather thickness and color, tissue density, capillary blood flows, and properties of longwave emissivity and shortwave absorption. The environmental temperature (i.e., equivalent blackbody temperature) combines ambient air temperature with heat energy losses from convection and longwave radiation at the body surface with heat energy gains absorbed from shortwave (solar) and longwave abiotic sources (e.g., water vapor, terrestrial features):

$T_{\mathrm{e}}=T_{\mathrm{a}}+\frac{r_{\mathrm{e}}}{\rho_{\mathrm{cp}}}\left(R_{\mathrm{abs}}-\varepsilon \sigma T_{\mathrm{a}}^{4}\right)$

where $\varepsilon \sigma T_{\mathrm{a}}{ }^{4}$ signifies heat lost from the body through longwave radiation imbalance with the environment, and $R_{\mathrm{abs}}$ is total heat energy absorbed from longwave and shortwave radiation.

The left side of equation 2 is the metabolic response to the energy flux existing between the organism and its environment. The $\lambda E$ is energy flux associated with mass transfer of water by evaporation from the organism to its abiotic environment. In the Aves, the energetically costly phase change from a water- to vapor state occurs about equally from the respiratory tract and cutaneous surface (Campbell and Norman 1998). Evaporation from the respiratory tract is a direct function of metabolic rate, whereas evaporation from skin surface is based on surface area of the organism. Latent heat loss of evaporation $(\lambda E)$ may account for approximately $20 \%$ of the maintenance energy budget, particularly when metabolic rates are high and air is dry, as would be during winter, when most DRC-1339 baitings occur. Generally, basal and thermoregulatory metabolism account for $40-60 \%$ of the daily energy budget of birds (Westerterp and Drent 1985). However, maintenance metabolism may reach $80 \%$ for some bird species during winter (Walsberg 1983).

\section{STUDY AREA}

Our study site was a mid-sized (20,000-head) cattle feeder operation near Great Bend, Kansas $\left(38.36^{\circ} \mathrm{N}, 98.79^{\circ} \mathrm{W}\right)$. It was an open-feeder system visited daily by many starlings. No blizzards or snow accumulation occurred during the study. Average minimum and maximum temperatures were $-8^{\circ} \mathrm{C}$ and $3^{\circ} \mathrm{C}$, respectively, over the 12 -day experiment from 11 to 22 January 2008; daily minima and maxima ranged from $-17^{\circ} \mathrm{C}$ to $14^{\circ} \mathrm{C}$ (Table 1). The 30-year average minimum and maximum temperatures were $-8^{\circ} \mathrm{C}$ and $5^{\circ} \mathrm{C}$, respectively.

\section{METHODS}

We simulated the site's environment diurnally in 24-hr segments, creating in the process an hourly series of $T_{\mathrm{e}} \mathrm{s}$. We used the middle day of the month of January and midlatitudinal coordinate of Kansas to calculate day length (Forsythe et al. 1995, eqs 1-3). We used day length to calculate the integer hours for sunrise and sunset using $1200 \mathrm{hr}$ as the constant for solar noon. To calculate direct and diffuse solar irradiance between sunrise and sunset, we used cloud type, cloud cover, sun declination at mid-month, Julian day, and latitude (Campbell and Norman 1998, eqs $11.1,11.8-11.13)$. We modeled hourly changes in ambient temperature using average monthly temperature and daily maximum and minimum temperatures (Campbell and Norman 1998, eqs 2.2-2.3). We used cloud cover and average daily ambient temperature to estimate longwave thermal emissivity of the physical surroundings, which we averaged with ground emissivity (held constant at 0.95) to derive one daily value for environmental emissivity (Campbell 1977, eq 5.13). We categorized average daily wind speed $(0 \mathrm{~km} / \mathrm{hr}, 8 \mathrm{~km} / \mathrm{hr}, 16 \mathrm{~km} / \mathrm{hr}$, or $32 \mathrm{~km} / \mathrm{hr})$ and adjusted it using an attenuation coefficient of 1.0 (Campbell and Norman 1998, eq 5.4). We calculated daily water vapor pressure (used for finding $\lambda$ ) $E$ using average 
Table 1. Comparisons of a bioenergetics model's estimate of daily metabolic rate $(\mathrm{M})$ with estimates based on feeding rates during 2-choice feeding preference tests using caged European starlings held outdoors during January 2008 in central Kansas.

\begin{tabular}{|c|c|c|c|c|c|c|c|c|c|c|c|c|}
\hline \multirow[b]{3}{*}{ Rep } & \multirow[b]{3}{*}{ Date } & \multirow{3}{*}{$\begin{array}{c}\text { Food/bird } \\
\bar{x}(g)^{\mathrm{a}}\end{array}$} & \multicolumn{4}{|c|}{ Daily metabolic rate (kJ) } & \multicolumn{6}{|c|}{ Meteorological variables } \\
\hline & & & \multicolumn{3}{|c|}{ Cage $(n=4)$} & \multirow{2}{*}{$\frac{\text { Model }}{\mathbf{M}^{\mathbf{b}}}$} & \multicolumn{3}{|c|}{ Temp $\left({ }^{\circ} \mathrm{C}\right)$} & \multirow[b]{2}{*}{ Wind $^{c}$} & \multicolumn{2}{|c|}{ Cloud $^{\mathrm{d}}$} \\
\hline & & & $\mathbf{M}$ & $\mathrm{L}_{95}$ & $\overline{U_{95}}$ & & Min. & Max. & $\bar{x}$ & & Type & $\%$ \\
\hline 1 & $\overline{11 \mathrm{Jan}}$ & 15 & 157 & 110 & 204 & $240^{*}$ & -4 & 10 & 3 & $\mathrm{M}$ & $\mathrm{N}$ & 0 \\
\hline 2 & 12 Jan & 19 & 177 & 144 & 211 & $254^{*}$ & -3 & 4 & 1 & $\mathrm{~L}$ & $\mathrm{~N}$ & 0 \\
\hline 3 & $13 \mathrm{Jan}$ & 24 & 206 & 169 & 243 & 208 & -6 & 7 & 1 & $\mathrm{~N}$ & $\mathrm{~N}$ & 0 \\
\hline 4 & $14 \mathrm{Jan}$ & 31 & 214 & 176 & 252 & 250 & -5 & 8 & 2 & M & $\mathrm{N}$ & 0 \\
\hline 5 & $15 \mathrm{Jan}$ & 20 & 232 & 195 & 269 & 236 & -6 & 14 & 4 & $\mathrm{~L}$ & $\mathrm{~N}$ & 0 \\
\hline 6 & 16 Jan & 28 & 211 & 145 & 276 & 259 & -7 & 4 & -2 & M & $\mathrm{S}$ & 100 \\
\hline 7 & 17 Jan & 27 & 209 & 157 & 261 & $271^{*}$ & -17 & -3 & -10 & $\mathrm{~L}$ & $\mathrm{~N}$ & 0 \\
\hline 8 & 18 Jan & 24 & 296 & 238 & 353 & 267 & -7 & -1 & -4 & $\mathrm{M}$ & $\mathrm{S}$ & 60 \\
\hline 9 & 19 Jan & 20 & 266 & 234 & 297 & 270 & -13 & -4 & -9 & $\mathrm{~L}$ & S & 80 \\
\hline 10 & $20 \mathrm{Jan}$ & 24 & 283 & 236 & 331 & 260 & -9 & 4 & -3 & $\mathrm{M}$ & $\mathrm{N}$ & 0 \\
\hline 11 & $21 \mathrm{Jan}$ & 25 & 298 & 247 & 349 & 274 & -10 & 0 & -5 & $\mathrm{H}$ & $\mathrm{S}$ & 100 \\
\hline 12 & $22 \mathrm{Jan}$ & 22 & 305 & 223 & 387 & 274 & -14 & -2 & -8 & M & $\mathrm{N}$ & 0 \\
\hline $\bar{x}$ & & 23 & 238 & & & 255 & -8 & 3 & -3 & & & \\
\hline
\end{tabular}

${ }^{\text {a }}$ Total amount of food eaten daily averaged per cage and divided by 6 to obtain individual feeding rate.

${ }^{\mathrm{b}}$ An asterisk indicates that the estimate of the bioenergetics model fell outside of the $95 \% \mathrm{CI}$.

${ }^{\mathrm{c}}$ Average daily wind speed categorized into None $(<8 \mathrm{~km} / \mathrm{hr})$, Low $(\geq 8 \mathrm{~km} / \mathrm{hr}$ and $<16 \mathrm{~km} / \mathrm{hr})$, Medium $(\geq 16 \mathrm{~km} / \mathrm{hr}$ and $<32 \mathrm{~km} / \mathrm{hr})$, and High $(\geq 32 \mathrm{~km} / \mathrm{hr}$ ).

${ }^{\mathrm{d}}$ Cloud type: $\mathrm{N}=$ None and $\mathrm{S}=$ Stratus.

daily temperature (Campbell 1977:20). We obtained meteorological variables from the Great Bend Municipal Airport, $20 \mathrm{~km}$ from the livestock facility.

We held core body temperature of starlings constant at $39.5^{\circ} \mathrm{C}$ (Brenner 1965, Dmi'el and Tel-Tzur 1985). We obtained bird mass by using Box-Mueller transformations to generate $z$-values based on a normal distribution of mass with a mean of $87 \mathrm{~g}(\mathrm{SD}=5)$. We calculated basal metabolism $\left(B_{\mathrm{M}}\right)$ and whole body resistance $\left(r_{\mathrm{b}}\right)$ using bird mass after subtraction of feather mass (Aschoff and Pohl 1970, Kendeigh 1970, Calder and King 1974). We used a $C$-value of 1.11 and a mass exponent of 0.64 for the basal metabolism equation (eq 1; Aschoff and Pohl 1970). We calculated whole body resistance using an equation from Calder and King (1974, Campbell and Norman 1998, eq 12.17). We calculated surface area of the body using bird mass (Campbell and Norman 1998, eq 12.13); we calculated volume (to find characteristic dimension, which we used to quantify convective resistances $\left[r_{\mathrm{a}}\right]$ ) using surface area of the body. We used characteristic dimension and wind speed to calculate Reynolds numbers for degrading resistance to forced convection $\left(r_{\mathrm{fo}}\right)$ at wind speeds $>0 \mathrm{~km} / \mathrm{hr}$ (Robinson et al. 1976, eq 5; Campbell and Norman 1998, Table 7.3). For no wind, we lowered $r_{\mathrm{fo}}$ resistance values by multiplying equation 5 of Robinson et al. (1976) by 0.7 to account for effects of random turbulence typically found in outdoor environments (Campbell and Norman 1998). We used regression equations to degrade whole-body resistance $\left(r_{\mathrm{b}}\right)$ caused by wind speeds $>0 \mathrm{~km} / \mathrm{hr}$ between sunrise and sunset (Robinson et al. 1976, Table 5). We calculated $\rho c_{\mathrm{p}}$ based on hourly changes in estimates of air temperature derived during the environmental simulation (Monteith 1973, Cartar and Guy Morrison 1997). We used the following formulae for calculating hourly values of radiative resistance $\left(r_{\mathrm{r}}\right)$ and environmental resistance $\left(r_{\mathrm{e}}\right)$, respectively
(Robinson et al. 1976, eq 4):

$r_{\mathrm{r}}=\frac{\rho_{\mathrm{cp}}}{4 \varepsilon \sigma T_{\mathrm{a}}{ }^{3}}$

where $\varepsilon$ is emissivity of the bird surface (0.98, from Walsberg and King 1978) and $\sigma$ is the Stefan-Boltzmann constant:

$r_{\mathrm{e}}=\frac{r_{\mathrm{r}} r_{\mathrm{a}}}{r_{\mathrm{r}}+r_{\mathrm{a}}}$

Lastly, we calculated absorbed radiation from shortwave and longwave sources hourly using the equation of Cartar and Guy Morrison (1997) and using a shortwave absorptivity coefficient of 0.76 and a shortwave aspect ratio $\left(A_{\text {ratio }}\right)$ of 0.22 (Walsberg and King 1978). We calculated latent heat exchange from respiratory and cutaneous surfaces using equations from Campbell and Norman (1998, eqs 12.15 and 12.16, respectively). We calculated exhalation temperature, used for calculating latent heat loss from respiration, using the regression of Engel et al. (2006). We calculated metabolic energy demand in hour segments (eq 2) and summed them over the 24-hr period to calculate the amount of energy required daily.

We estimated metabolic rates from feeding rates using 4 cages $(1.2 \mathrm{~m} \times 1.2 \mathrm{~m} \times 2.4 \mathrm{~m})$, each holding 6 starlings trapped at the feedlot. The starlings were subjects in a serial, 2-choice test involving preferences for 6 potential DRC1339 bait substrates (see Homan et al. 2010). We conducted the test over 12 consecutive mornings, starting $0.5 \mathrm{hr}$ before sunrise and ending $4 \mathrm{hr}$ later. Briefly, at $0.5 \mathrm{hr}$ before sunrise, we placed 2 clear plastic trays (dimensions $6 \mathrm{~cm} \times 23 \mathrm{~cm} \times 33 \mathrm{~cm}$ ) each containing $114 \mathrm{~g}$ of bait side-by-side on the floor of the cage with the order of presentation (left-to-right) determined by coin flip on test 1 and alternated each test thereafter. We provided a $142-\mathrm{g}$ portion of maintenance food (dry cat chow) after the 4-hr 
test and removed it $0.5 \mathrm{hr}$ before sunset. We weighed all foods to the nearest $0.1 \mathrm{~g}$ before placing them in cages and we reweighed them after removal. We used the difference between the 2 measurements, after accounting for spillage, as the amount of food consumed. We divided the amount of each food eaten by 6 to obtain an estimate of daily individual feeding rate per cage.

We estimated metabolizable energy of the nutrient classes using digestion coefficients for starlings fed poultry feed (Thompson and Grant 1968). Digestion coefficients were 0.38 for carbohydrate, 0.37 for protein, 0.74 for fat, and 0.17 for fiber. We used energy yields of $17 \mathrm{~kJ} / \mathrm{g}$ for crude protein and carbohydrate, $37 \mathrm{~kJ} / \mathrm{g}$ for crude fat, and $8 \mathrm{~kJ} / \mathrm{g}$ for crude fiber. We obtained percentages of nutritional contents in each food through guaranteed-analysis labeling on the products. We calculated percentage carbohydrate by subtracting the percentages of moisture, protein, fiber, fat, and ash. We conducted our research under approval by the National Wildlife Research Center, Fort Collins, Colorado (Quality Assurance [QA] study protocols QA-1110 and QA-1337). Protocols were approved by the National Wildlife Research Center's Institutional Animal Care and Use Committee prior to initiation of the studies.

We compared estimates of daily metabolic rate between the bioenergetics model and feeding-rate model with paired$t$ tests. We tested for correlation between estimates with Pearson product moment correlations. We accepted statistical significance at $\alpha \leq 0.05$. We based model estimates of daily metabolic rate on average of metabolic rates of 10,000 birds drawn from the normal distribution of bird masses. To test daily consistency in estimates generated by the bioenergetics model, we created $95 \%$ confidence intervals using variation of daily metabolic rates among cages $(n=4)$. We used means and standard deviations to show central tendency and variance of the data. We created the bioenergetics model using Visual Basic ${ }^{\circledR}$ for Applications, with Excel ${ }^{\circledR}$ as the application platform (Microsoft, Redmond, WA).

\section{RESULTS}

The bioenergetics model predicted metabolic rates ranging from $208 \mathrm{~kJ} /$ bird per day to $274 \mathrm{~kJ} / \mathrm{bird}$ per day (Table 1 ). Metabolic rates from feeding-rate measurements indicated 157-305 kJ/bird per day. There was no difference between the 2 models' estimates of daily metabolic rate (paired $t$-test: $\left.t_{(11)}=1.4, P=0.18\right)$. Estimates from the bioenergetics model were within $95 \%$ confidence intervals of estimates based on feeding-rates on 9 of 12 days and greater than the upper $95 \%$ confidence interval on 3 days. Estimates of metabolic rate from the feeding-rate model and bioenergetics model were directly correlated $\left(r_{12}=0.57, P=0.05\right)$. Metabolic rates from the feeding-rate model were correlated with minimum $\left(r_{12}=-0.66, P=0.02\right)$, maximum $\left(r_{12}=-0.67, P=0.02\right)$, and average daily ambient temperatures $\left(r_{12}=-0.72, P=0.009\right)$, whereas estimates from the bioenergetics model were not correlated with these variables ( $r$-values: -0.13 to $-0.24, P$-values: $0.46-0.69)$. Average $T_{\mathrm{e}}$ for the 12 -day study period was $-2^{\circ} \mathrm{C}$, compared with an average $T_{\mathrm{amb}}$ of $-3^{\circ} \mathrm{C}$. The greatest divergence between average $T_{\mathrm{amb}}$ and $T_{\mathrm{e}}$ was on 17 January, the coldest day of the study, when average $T_{\mathrm{amb}}$ and $T_{\mathrm{e}}$ were $-10^{\circ} \mathrm{C}$ and $-7^{\circ} \mathrm{C}$, respectively. Average metabolic rate was $238 \mathrm{~kJ} /$ day $(n=12, \mathrm{SD}=48)$ based on the feeding-rate model, whereas average from the bioenergetics model was $255 \mathrm{~kJ} /$ day $(\mathrm{SD}=19)$. Contributions of the categorized metabolic components from the bioenergetics model were as follows: $31 \%$ basal metabolism ( $\mathrm{SD}=2.7), 58 \%$ thermoregulatory metabolism $(\mathrm{SD}=3.6)$, and $11 \%$ evaporative heat-loss $(\mathrm{SD}=0.9)$.

\section{DISCUSSION}

Although independently derived, our models' estimates of daily metabolic rate were comparable. Our estimates were also similar to estimates of metabolic rates for starlings in the literature. Doubly labeled water is probably the best field method available for measuring daily metabolic rate. The DLW method requires recapturing to make the estimate, and pre- and postmeasurements are needed to determine differences in levels of hydrogen and oxygen isotopes (Ehleringer et al. 1986). Most DLW studies on birds have been conducted during the reproductive period because it presents the best opportunity for making recaptures. Moreover, estimates of daily metabolic rate using the DLW technique also include activity metabolism, and thus we can make no direct comparison with our results. However, our estimates did fall in the approximate middle of the $95 \%$ confidence interval (115-389 kJ/day) generated from allometric regression of DLW measurements for large passerine species (Nagy et al. 1999). Empirically, DLW measurements indicated that starlings, during the reproductive period, need about $269 \mathrm{~kJ} /$ day of energy (Nagy et al. 1999), close to the predicted range of 233-260 kJ/day for starlings during the reproductive period, based on potential physiological limitations of multiple scaling of basal metabolic rate to achieve probable maximum energy intake (Kirkwood 1983, Dann et al. 1990).

Johnson and McTaggart-Cowan (1975) estimated that starlings had a daily metabolic rate requiring $262 \mathrm{~kJ}$ during winter, as calculated from the amounts of metabolizable energy consumed by starlings held in an outdoor aviary during January, when average ambient temperature was $-2.1^{\circ} \mathrm{C}$. Our bioenergetics model predicted an average daily rate of $255 \mathrm{~kJ}$, during which average ambient temperature was $-3^{\circ} \mathrm{C}$. Our estimates of metabolic rate and those from Johnson and McTaggart-Cowan (1975) were much higher than the predicted metabolic rate of an $85-\mathrm{g}$ bird at $-3^{\circ} \mathrm{C}$ (193 kJ/day) by Kendeigh (1970) and Kendeigh et al. (1977) using temperature dependent regression equations. We agree with the speculation of Johnson and McTaggart-Cowan (1975) that perhaps differences with estimates of daily metabolic rate by Kendeigh (1970) and Kendeigh et al. (1977) were caused by our use of larger cage sizes, which allowed birds a modicum of flight. Moreover, birds in our study were perhaps disrupted more often by the intense amount of daily activity involved with feeding and maintaining 20,000 head of livestock. Finally, the generalized nature of 
Kendeigh's regression equation (based on 15 passerine and 9 non-passerine species) may have contributed to differences between metabolic estimates. Kendeigh et al. (1977) estimated that the cost of activity of free-living could be up to $30 \%$ of maintenance metabolism. Under this assumption, a free-living starling weighing $85 \mathrm{~g}$ should have a metabolic rate of about $251 \mathrm{~kJ} / \mathrm{day}$ at an ambient air temperature averaging $-3^{\circ} \mathrm{C}$. A $251-\mathrm{kJ} /$ day metabolic rate represents approximately $58 \%$ of the predicted maximum achievable metabolic rate $(432 \mathrm{~kJ} / \mathrm{bird}$ per day) of winter acclimatized starlings (Lustick and Adams 1977). Starlings visiting our study feedlot roosted $18 \mathrm{~km}$ away, which would have an estimated flight cost of $26 \mathrm{~kJ}$ per round trip (Torre-Bueno and LaRochelle 1978); this cost, plus additional time spent in flight at the feedlot (approx. $6 \mathrm{~kJ}$, see Walsberg 1983, eq 11) would give a daily energy expenditure of $287 \mathrm{~kJ} / \mathrm{bird}$ per day.

Both $T_{\mathrm{amb}}$ and $T_{\mathrm{e}}$ were highly correlated, thus we were surprised that we found no significant correlation between daily ambient temperatures and metabolic estimates from the bioenergetics model. The lack of correlation was caused by interactions of other variables in the model that countered effects of temperature, particularly wind (Walsberg and King 1980, Walsberg 1986). For example when we excluded wind categories Low and None, the correlation between the $T_{\mathrm{amb}}$ and the model's estimate of daily metabolic rate was $r_{7}=-0.66(P=0.098)$.

Although DRC-1339 is highly toxic to starlings, it is a slow-acting compound, and direct quantification of DRC1339 mortality is problematic because affected birds have time to leave the baiting site (DeCino et al. 1966). Prior to development of the model for Compound DRC-1339 Concentrate-Feedlots, mortality assessments (i.e., take) were generally made by counting birds pre- and posttreatment. Counting birds in dense, often swirling, flocks creates potential for miscounting, particularly undercounting (Faanes and Bystrak 1981, Bibby et al. 2000, Frederick et al. 2003). Additionally, the lack of precision in counts can produce the anomalous result of having some or all of the DRC-1339 baits removed from a site, yet no mortality because posttreatment counts were equal or greater than pretreatment counts (Homan et al. 2005). This anomaly may be from miscounting, imprecision, or an influx of new birds to a treated site. The DRC-1339 mortality model is advantageous because only an estimate of the amount of baits removed is needed to make an assessment of mortality, thereby avoiding chance events and errors that decrease precision and accuracy of counts. Our bioenergetics model was designed to be used only within the mortality model for the EPA pesticide label, Compound DRC-1339 Concentrate-Feedlots. We are developing a similar model for starlings and blackbirds (Icteridae) under the label, Compound DRC-1339 Concentrate-Staging Areas, which will broaden use of modeling to quantify mortality. Use of DRC-1339 under the Staging Area label often involves bird depredation of grain and fruit crops, a widespread problem faced by many resource managers in Wildlife Services.

\section{MANAGEMENT IMPLICATIONS}

In 2008, Wildlife Services began using the DRC-1339 mortality model to standardize and improve estimates of starling take at livestock facilities. Adoption of our model resulted in a nearly 100\% increase in Wildlife Services' reported annual take of starlings compared to 2007. Before 2008, we speculate that take was probably underestimated for baitings conducted under the DRC-1339 Feedlots label. In comparison to counts, our model represents a more rigorous and scientifically justifiable approach for estimating starling take at livestock facilities. Lastly in addition to being used as a model component in estimating take, our bioenergetics model could be used to predict the amount of livestock feed a set number of starlings (e.g., 1,000) could eat over a fixed time period under prescribed metrological conditions.

\section{ACKNOWLEDGMENTS}

We thank the following for their support and assistance with our project: A. Galle, S. Gaukler, T. Halstead, L. Penry, B. McLean, G. Salter, North Dakota State University, and Kansas Wildlife Services. The Study Director was H. J. Homan.

\section{LITERATURE CITED}

Aschoff, J., and H. Pohl. 1970. Rhythmic variations in energy metabolism. Federation Proceedings 29:1541-1552.

Bakken, G. S. 1976. A heat transfer analysis of animals: unifying concepts and the application of metabolism chamber data to field ecology. Journal of Theoretical Biology 60:337-384.

Bakken, G. S., and D. M. Gates. 1975. Heat transfer analysis of animals: some implications for field ecology, physiology, and evolution. Pages 255290 in D. M. Gates and R. B. Schmerl, editors. Perspectives in biophysical ecology. Springer, New York, New York, USA.

Bibby, C. J., N. D. Burgess, D. A. Hill, and S. Mustoe. 2000. Bird census techniques. Second Edition. Academic Press, London, United Kingdom.

Brenner, F. J. 1965. Metabolism and survival time of grouped starlings at various temperatures. Wilson Bulletin 77:388-395.

Calder, W. A., and J. R. King. 1974. Thermal and caloric relations of birds. Pages 259-413 in D. S. Farner and J. R. King, editors. Avian biology IV. Academic Press, New York, New York, USA.

Campbell, G. S. 1977. An introduction to environmental biophysics. Springer-Verlag, New York, New York, USA.

Campbell, G. S., and J. M. Norman. 1998. An introduction to biophysics. Second Edition. Springer-Verlag, New York, New York, USA.

Cartar, R. V., and R. I. Guy Morrison. 1997. Estimating metabolic costs for homeotherms from weather data and morphology: an example using calidridine sandpipers. Canadian Journal of Zoology 75:94-101.

Dann, S., D. Masman, and A. Groenewold. 1990. Avian basal metabolic rates: their association with body composition and energy expenditure in nature. American Journal of Physiology 259:R333-R340.

DeCino, T. J., D. J. Cunningham, and E. W. Schafer, Jr., 1966. Toxicity of DRC-1339 to starlings. Journal of Wildlife Management 30:249-253.

Dmi'el, R., and D. Tel-Tzur. 1985. Heat balance of two starling species (Sturnus vulgaris and Onychognathus tristrami) from temperate and desert habitats. Journal of Comparative Physiology B: Biochemical, Systemic, and Environmental Physiology 155:395-402.

Engel, S., R. A. Suthers, H. Biebach, and G. H. Visser. 2006. Respiratory water loss during rest and flight in European Starlings (Sturnus vulgaris). Comparative Biochemistry and Physiology-Part A: Molecular and Integrative Physiology 145:423-432.

Ehleringer, J. R., P. W. Rundel, and K. A. Nagy. 1986. Stable isotopes in physiological ecology and food web research. Trends in Ecology and Evolution 1:42-45. 
Faanes, C. A., and D. Bystrak. 1981. The role of observer bias in the North American breeding bird survey. Pages 353-359 in C. J. Ralph and J. M. Scott, editors. Estimating the numbers of terrestrial birds. Studies in Avian Biology 6.

Forsythe William, C., E. J. Rykiel, Jr., R. S. Stahl, H. Wu, and R. M. Schoolfield. 1995. A model comparison for daylength as a function of latitude and day of year. Ecological Modelling 80:87-95.

Frederick, P. C., B. Hylton, J. A. Heath, and M. Ruane. 2003. Accuracy and variation in estimates of large numbers of birds by individual observers using an aerial survey simulator. Journal of Field Ornithology 74:281-287.

Glahn, J. F., D. J. Twedt, and D. L. Otis. 1983. Estimating feed loss from starling use of livestock feed troughs. Wildlife Society Bulletin 11:366372.

Homan, H. J., R. S. Stahl, J. J. Johnston, and G. M. Linz. 2005. Estimating DRC-1339 mortality using bioenergetics: a case study of the European starling. Proceedings of the Wildlife Damage Management Conference 11:202-208

Homan, H. J., G. M. Linz, S. Beckerman, A. G. Duffiney, and T. D. Halstead. 2010. European starling preferences for bait substrates used in DRC-1339 applications. Human-Wildlife Interactions 4:25-31.

Johnson, S. R., and I. McTaggart-Cowan. 1975. The energy cycle and thermal tolerance of the starlings (Aves, Sturnidae) in North America. Canadian Journal of Zoology 53:55-68.

Johnston, J. J., R. S. Stahl, H. J. Homan, G. M. Linz, and W. C. Pitt. 2007. Probabilistic bioenergetic/toxicity modeling approach for estimating toxicant induced mortality to target invasive species and non-target wildlife. Pages 393-397 in G. W. Witmer, W. C. Pitt, and K. A. Fagerstone, editors. Managing vertebrate invasive species. Proceedings of an International Symposium. U.S. Department of Agriculture/Animal and Plant Health Inspection Service/Wildlife Services, National Wildlife, Research Center, Fort Collins, Colorado, USA.

Kendeigh, S. C. 1969. Energy responses of birds to their thermal environments. Wilson Bulletin 81:441-449.

Kendeigh, S. C. 1970. Energy requirements for existence in relation to size of bird. Condor 72:60-65.

Kendeigh, S. C., V. R. Dol'nik, and V. M. Gavrilov. 1977. Avian energetics. Pages 127-204 in J. Pinowski and S. C. Kendeigh, editors. Granivorous birds in ecosystems. Cambridge University Press, New York, New York, USA.

Kelty, M. P., and S. I. Lustick. 1977. Energetics of the starling (Sturnus vulgaris) in a pine woods. Ecology 58:1181-1185.

Kirkwood, J. A. K. 1983. A limit to metabolizable intake in mammals and birds. Comparative Biochemistry and Physiology—Part A: Comparative Physiology 75:1-3.
Lustick, S., and J. Adams. 1977. Seasonal variation in the effects of wetting on the energetics and survival of starlings (Sturnus vulgaris). Comparative Biochemistry and Physiology—Part A: Comparative Physiology 56:173177.

Mahoney, S. A., and J. R. King. 1977. The use of equivalent blackbody temperature in the thermal energetics of small birds. Journal of Thermal Biology 2:115-120.

Monteith, J. L. 1973. Principles of environmental physics. Elsevier, New York, New York, USA.

Nagy, K. A., I. A. Girard, and T. K. Brown. 1999. Energetics of free-ranging mammals, reptiles, and birds. Annual Reviews of Nutrition 19:247277.

Pitt, W. C., D. A. Beauchamp, and M. R. Conover. 1998. Evaluation of bioenergetics models for predicting great blue heron consumption of rainbow trout at hatcheries. North American Journal of Fisheries Management 18:52-65.

Robinson, D. E., G. S. Campbell, and J. R. King. 1976. An evaluation of heat exchange in small birds. Journal of Comparative Physiology 105:153166.

Thompson, R. D., and C. V. Grant. 1968. Nutritive value of two laboratory diets for starlings. Laboratory Animal Care 18:75-79.

Torre-Bueno, J. R., and J. LaRochelle. 1978. The metabolic cost of flight in unrestrained birds. Journal of Experimental Biology 75:223-229.

Walsberg, G. E. 1983. Avian ecological energetics. Pages 161-220 in D. S. Farner, J. R. King, and K. C. Parkes, editors. Avian biology VII, Academic Press, New York, New York, USA.

Walsberg, G. E. 1986. Thermal consequences of roost-site selection: the relative importance of three modes of heat conservation. Auk 103:1-7.

Walsberg, G. E., and J. R. King. 1978. The energetic consequences of incubation for two passerine species. Auk 95:644-655.

Walsberg, G. E., and J. R. King. 1980. The thermoregulatory significance of the winter roost-sites selected by robins in eastern Washington. Wilson Bulletin 92:33-39.

Westerterp, K. R., and R. Drent. 1985. Energetic costs and energy-saving mechanisms in parental care of free-living passerine birds as determined by the $\mathrm{D}_{2}{ }^{18} \mathrm{O}$ method. Proceedings International Ornithological Congress 18:392-398.

Wiersma, P., and T. Piersma. 1994. Effects of microhabitat, flocking, climate and migratory goal on energy expenditure in the annual cycle of red knots. Condor 96:257-279.

Associate Editor: Graham Hall. 